Kong. Res. J. 3(1) : 88-90, 2016

ISSN 2349-2694

Kongunadu Arts and Science College, Coimbatore.

\title{
CITATION ANALYSIS OF THE “JOURNAL OF DIGITAL INFORMATION MANAGEMENT”
}

\author{
Senthilkumar, $\mathbf{R}^{{ }^{*}}{ }^{*}, \mathrm{G}$. Ulaganathan ${ }^{2}$ and M. Muthukrishnan ${ }^{3}$ \\ ${ }^{1}$ Librarian (SG) \& Head (Research), Department of Library and Information Science, Kongunadu Arts \& \\ Science College (Autonomous), Coimbatore-641 029. \\ ${ }^{2}$ Librarian, Dr. SNS Rajalakshmi College of Arts \& Science (Autonomous), Coimbatore-641 049. \\ ${ }^{3}$ Librarian, Dr. N.G.P. Arts \& Science College (Autonomous), Coimbatore - 641048. \\ *E.mail: kasclibrary@yahoo.com
}

\begin{abstract}
This paper presents a Citation Analysis of the Journal of Digital Information Management for the period between 2010 to 2014. The analysis covers mainly the Volume-wise Distribution of Citations, Distribution of Citations According to Bibliographic Forms, Authorship Pattern of Citations, Chronological Distribution of Citations, Author self citation. All the studies point towards the merits and weaknesses of the Journal which will be helpful for its further development. The study reveals that the average citations per article are 17.64. The study also found that journals/serial publications remain the most useful source of information 1896 (41.28\%) out of a total 4593 citations.
\end{abstract}

Keywords: Citation analysis, Bibliography, Authorship pattern.

\section{INTRODUCTION}

The essence of Journal publishing is to report research findings and to contribute to the field of knowledge. Journals are the most current channel of dissemination of new ideas, knowledge and breakthroughs in scientific development. Academic journals play a significant role in academic scholarship (Xiao and Smith, 2006) (Chandy and William, 1994). Citations appearing in journals of particular disciplines provide an objective measure of the contributions of other knowledge systems to the development and progress of that particular discipline (Chandy and Williams, 1994). According to Gao, Yu, and Luo (2009) librarians have used several different quantitative methods to identify patrons' needs, including circulation and shelving data, the analysis of inter library loan requests, as well as citation analysis. Edward (1999) asserts that citation analysis can be used to determine a core collection of journals critical to local users and representative of the research needs of the collection. Gooden (2001) opines that citation analysis has been used by Librarians in various disciplines to eliminate costly, low used/unused journals, purchase needed materials and ascertain core journals needed for patron use, and to reveal the most active research in a particular field. Ching and Chennupati (2002) opine that citation analysis is a form of checklist approach, and basically compares a library's holdings to an authoritative list for the purpose of assessing the quality of all or part of the collection.
The current study is a citation analysis of the Journal of Digital Information Management for the period between 2010-2014.The journal of Digital Information Management (JDIM), a $\mathrm{Bi}$ monthly Journal of Digital Information Science and Technology, has been published since March 2003.Sponsored by the Digital Information Research Foundation, it concentrates on all aspects of digital information management, and covers digital information processing, digital content management, digital world structuring, digital libraries, metadata, information management and other related fields. An International peer-reviewed journal, it acts as a portal to the digital information world.

\section{RESULS}

Five volumes (Volumes 8 to 12) each containing 6 issues of Journal of Digital Information Management have been taken up for the study. The details with regard to each published article such as Volume-wise Distribution of Citations, Distribution of Citations According to Bibliographic Forms, Authorship Pattern of Citations, Chronological Distribution of Citations, Author Self citation were recorded and analyzed for making observations.

The Journal published 266 articles during the period of study i.e. from Vol.8.-12 (Year 20102014). The Journal publishes on an average of 17.64 citations per article. The above Table shows that the maximum number of citations per article was in the volume number 8 with $1055(21.10 \%)$ out of 4593 total citations. 
Table 1. Volume-wise distribution of citations

\begin{tabular}{cccc}
\hline $\begin{array}{c}\text { Volume } \\
\text { Number }\end{array}$ & $\begin{array}{c}\text { Number } \\
\text { of } \\
\text { Articles }\end{array}$ & $\begin{array}{c}\text { Number } \\
\text { of } \\
\text { Citations }\end{array}$ & $\begin{array}{c}\text { Average } \\
\text { Citations per } \\
\text { Article }\end{array}$ \\
\hline 8 & 50 & 1055 & 21.10 \\
9 & 41 & 762 & 18.59 \\
10 & 53 & 967 & 18.25 \\
11 & 72 & 972 & 13.50 \\
12 & 50 & 837 & 16.74 \\
\hline Total & 266 & 4593 & 17.64 \\
\hline
\end{tabular}

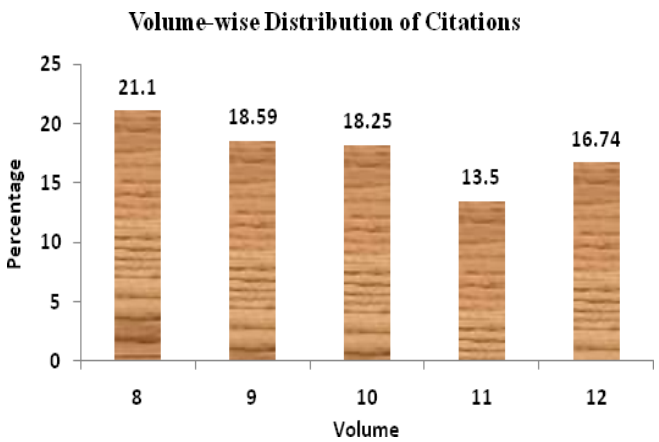

Table 2. Distribution of citations according to bibliographic forms remaining articles. However, there are 73 (1.59\%)

citations with incomplete details on the authorship.

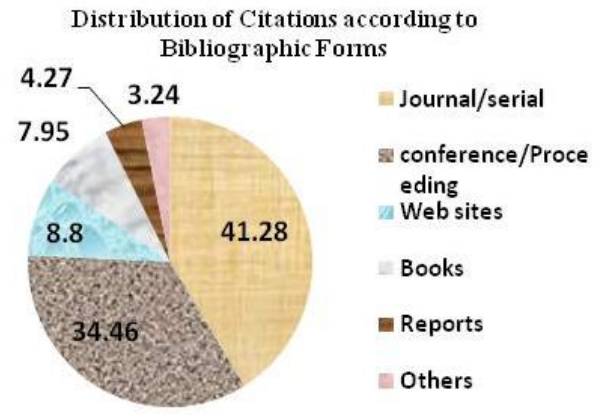

Table 3. Authorship Pattern of Citations

\begin{tabular}{cccc}
\hline $\begin{array}{c}\text { Number of } \\
\text { Authors }\end{array}$ & $\begin{array}{c}\text { Number of } \\
\text { Citations }\end{array}$ & Percentage & Ranking \\
\hline One & 294 & 6.40 & V \\
Two & 671 & 14.61 & III \\
Three & 1727 & 37.60 & I \\
Four & 1339 & 29.15 & II \\
Five & 351 & 7.64 & IV \\
Six & 138 & 3.01 & VI \\
Incomplete & 73 & 1.59 & VII \\
\hline Total & 4593 & 100 & \\
\hline
\end{tabular}

\begin{tabular}{cccc}
\hline $\begin{array}{c}\text { Bibliographic } \\
\text { Form }\end{array}$ & $\begin{array}{c}\text { Number } \\
\text { of } \\
\text { Citations }\end{array}$ & $\begin{array}{c}\text { Percenta } \\
\text { ge }\end{array}$ & $\begin{array}{c}\text { Ranki } \\
\text { ng }\end{array}$ \\
\hline $\begin{array}{c}\text { Journals/Serial } \\
\text { Publications }\end{array}$ & 1896 & 41.28 & I \\
$\begin{array}{c}\text { Conference/Proc } \\
\text { eedings }\end{array}$ & 1583 & 34.46 & II \\
Web sites & 404 & 8.80 & III \\
Books & 365 & 7.95 & IV \\
Reports & 196 & 4.27 & V \\
Others & 149 & 3.24 & VI \\
\hline Total & 4593 & 100 & \\
\hline
\end{tabular}

Table 2 shows the analysis of citations according to bibliographic forms of the 4593 citations, as many as $1896(41.28 \%)$ are from Journal/Serial publications, followed by Conference/Proceedings 1583(34.46\%), Websites 404(8.80\%), Books 365 (7.95\%), Reports 196 (4.27\%) and Others $149(3.24 \%)$.

Table 3 shows the authorship pattern of citations as appended to the References Section of 266 research articles of Journal of Digital Information Management, the source journal. The Table indicates that out of the total of 4593 citations, $1727(37.60 \%)$ are three-authored, followed by four-authored contributions totaling 1339 (29.15\%), and two -authored contributions totaling 671 (14.61\%), five or six authors contributed the

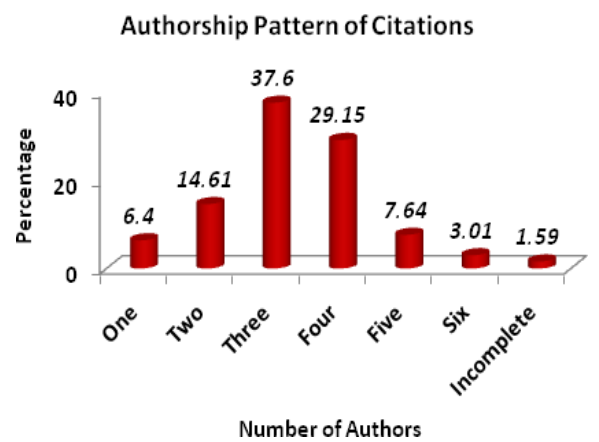

Table 4. Chronological Distribution of Citations

\begin{tabular}{cccc}
\hline $\begin{array}{c}\text { Span of } \\
\text { Period }\end{array}$ & $\begin{array}{c}\text { Number of } \\
\text { Citations }\end{array}$ & Percentage & Rank \\
\hline $1930-1939$ & 3 & 0.07 & IX \\
$1940-1949$ & 4 & 0.09 & VIII \\
$1950-1959$ & 4 & 0.09 & VIII \\
$1960-1969$ & 13 & 0.28 & VII \\
$1970-1979$ & 44 & 0.96 & VI \\
$1980-1989$ & 146 & 3.18 & IV \\
$1990-1999$ & 518 & 11.28 & III \\
$2000-2009$ & 2744 & 59.74 & I \\
$2010-2014$ & 1035 & 22.53 & II \\
Unknown & 82 & 1.78 & V \\
period & & & \\
\hline Total & 4593 & 100 & \\
\hline
\end{tabular}


Table 4 gives the chronological distribution of citations. The result indicates that the period 2000-2009 received the most citations, 2744 (59.74\%) of the total citations in terms of chronological distribution of citations. It is noticed, however, that of the 4593 citations counted, 82 (1.78 $\%$ ) citations had incomplete data pertaining to the year of publication.

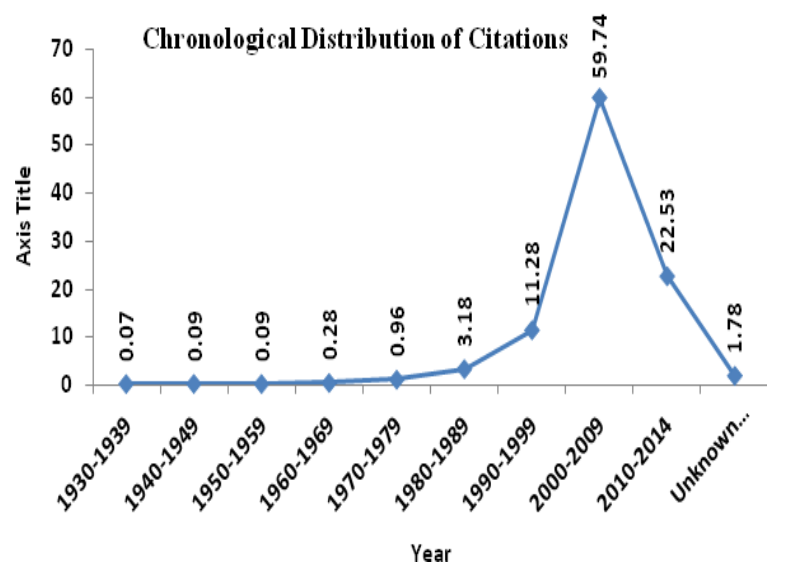

Table 5. Author Self citation

\begin{tabular}{ccc}
\hline Year & $\begin{array}{c}\text { Number of Author S elf } \\
\text { citation }\end{array}$ & Percentage \\
\hline 2010 & 63 & 20.32 \\
2011 & 42 & 13.55 \\
2012 & 81 & 26.13 \\
2013 & 67 & 21.61 \\
2014 & 57 & 18.39 \\
\hline Total & 310 & 100 \\
\hline
\end{tabular}

\section{Author Self Citation}

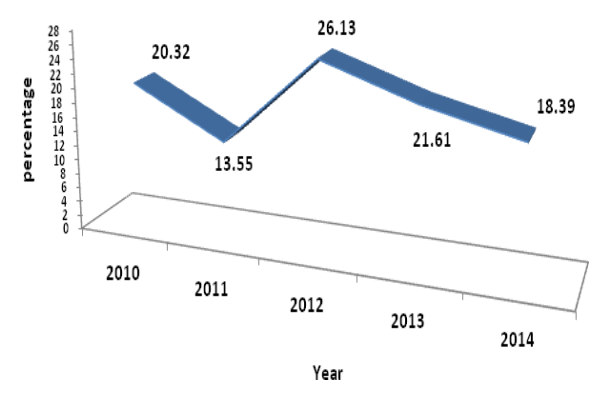

Self-citation occurs when an author cites any of his articles written singly or jointly with others. In this study we found 310 author self citations that amount to $6.75 \%$ of total citations. The above Table shows the year wise author self citations during the year 2012, maximum number of author self citations $81(26.13 \%)$.

\section{CONCLUSION}

Citation Analysis reveals that between 20102014 every issue of Journal of Digital Information Management published an average citation per article 17.64. The study reveals that journals/serial publications remain the most useful source of information 1896 (41.28\%) out of a total 4593 citations. The authorship pattern of citations reveals very clearly that scientists are moving towards collaborative research, as the majority of citations $1727 \quad(37.60 \%)$ are three-authored. The chronological distribution of citations indicates that scientists are quite up-to-date as references cited are fairly recent with $2744(59.74 \%)$ published between 2000-2009. During this study we found 310 author self citations that amount to $6.75 \%$ of total citations.

\section{REFERENCES}

Chandy, P.R. and T.G. William, (1994). The impact of Journals and Authors on International Business Research: A Citation Analysis of JIBS Articles. J. Int. Business Stud. 25(4).

Ching, J.T.Y. and K.R. Chennupati, (2002). Collection Evaluation Through Citation Analysis Techniques: A Case Study of the Ministry of Education, Singapore. Library Review 51(8):398-405.

Edward, S. (1999). Citation Analysis as a Collection Development Tool: A Bibliometric Study of Polymer, Science Theses and Dissertation. Serials Reward 25(1):11-20.

Gao, S.J., W.Z. Yu and F.P. Luo, (2009). Citation Analysis of Ph.D Thesis at Wuhan University, China. Library Collections, Acquisitions, \& Technical Services 33: 8-16.

Gooden, A.M. (2001). Citation Analysis of Chemistry Doctoral Dissertation: An Ohio State University Case Study. Issues in Science and Technology Librarianship, (Fall). Available: http://www.istl.org/01- fall/refereed.html.

Xiao, H. and S.L.J. Smith, (2006). The Making of Tourism Research: Insights from a Social Sciences Journal. Ann. Tour. Res. 33(2): 490507. 